
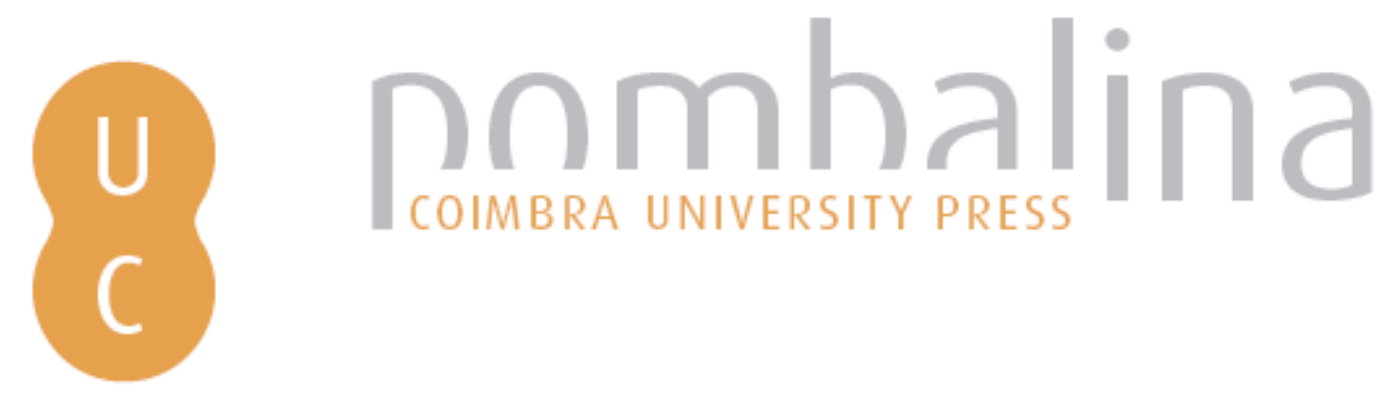

\title{
Building the prototype for a new National Fire Danger Rating System for Australia
}
Autor(es): Simon; Hollis, Jennifer; Kenny, Belinda; Sauvage, Samuel; Shackleton, Corey; Short, Lew; Sparkes, Deb

Publicado por: Imprensa da Universidade de Coimbra

URL persistente:

URI:http://hdl.handle.net/10316.2/44695

DOI:

DOI:https://doi.org/10.14195/978-989-26-16-506_178

Accessed : $\quad$ 26-Apr-2023 12:02:22

A navegação consulta e descarregamento dos títulos inseridos nas Bibliotecas Digitais UC Digitalis, UC Pombalina e UC Impactum, pressupõem a aceitação plena e sem reservas dos Termos e Condições de Uso destas Bibliotecas Digitais, disponíveis em https://digitalis.uc.pt/pt-pt/termos.

Conforme exposto nos referidos Termos e Condições de Uso, o descarregamento de títulos de acesso restrito requer uma licença válida de autorização devendo o utilizador aceder ao(s) documento(s) a partir de um endereço de IP da instituição detentora da supramencionada licença.

Ao utilizador é apenas permitido o descarregamento para uso pessoal, pelo que o emprego do(s) título(s) descarregado(s) para outro fim, designadamente comercial, carece de autorização do respetivo autor ou editor da obra.

Na medida em que todas as obras da UC Digitalis se encontram protegidas pelo Código do Direito de Autor e Direitos Conexos e demais legislação aplicável, toda a cópia, parcial ou total, deste documento, nos casos em que é legalmente admitida, deverá conter ou fazer-se acompanhar por este aviso.

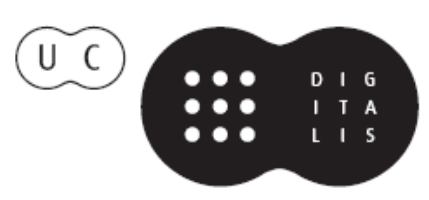




\section{ADVANCES IN}

\section{FOREST FIRE RESEARCH}

\section{8}

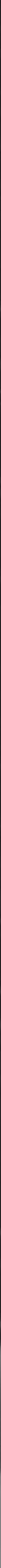


Short contribution - Decision Support Systems and Tools

Building the prototype for a new National Fire Danger Rating System for Australia

Stuart Matthews ${ }^{1 *}$; Paul Fox-Hughes ${ }^{2}$; Saskia Grootemaat ${ }^{1}$, Simon Heemstra ${ }^{1}$, Jennifer Hollis ${ }^{1}$, Belinda

Kenny $^{1}$, Samuel Sauvage ${ }^{2}$, Corey Shackleton ${ }^{1}$, Lew Short ${ }^{3}$, Deb Sparkes ${ }^{3}$

${ }^{I}$ NSW Rural Fire Service, Lidcome, NSW 2142, Australia, \{stuart.matthews@rfs.nsw.gov.au*\}

${ }^{2}$ Bureau of Meteorology, Melbourne, VIC 2001, Australia

${ }^{3}$ Australasian Fire and Emergency Services Authorities Council

Keywords: fire danger; fuel; fire behavior; fire weather;

\section{Introduction}

In July 2014, Senior Officers and Ministers agreed that the development of a new National Fire Danger Rating System is a national priority. The current system is based on science and research developed in the 1960s and does not meet the needs of emergency service authorities or the community in achieving the best emergency management outcomes in a bushfire event.

The National Fire Danger Rating System Program (the Program) will implement significant improvements to the system in the areas of fire weather prediction, fire ignition and behaviour potential and the impact on life, assets and the environment. The Program is designed to strengthen the ability of fire authorities to accurately communicate bushfire risk to the community, enhance agency readiness and preparedness and contribute to risk management.

It was decided to take a phased approach to maintain momentum and provide a better understanding of what needs to be done and funded to achieve a new system for Australia. This includes the development of a research prototype fire danger rating system, which the NSW Rural Fire Service (RFS) and Bureau of Meteorology (BoM) built and tested in the 2017/18 southern fire season.

\section{Improving ratings}

Fire danger is a general term, representing many factors culminating in a fire environment; ignition potential or fire hazard, risk, rate of spread, difficulty of control, fire impact(s) and safety. Fire danger rating is a valuable tool in communicating bushfire risk to the community, not only by increasing public awareness but also as a trigger for notification of potential threats. Importantly, because of its foundation in fire weather and behaviour, fire danger rating also provides a tool for decision making in fire suppression operations as well as supporting prescribed burning. It is for operational fire management that we aim to address how the fire danger ratings will be defined as well as the thresholds between categories.

To establish these fire danger ratings and to ensure they are accurate, relevant, clear and useful, we sought input from fire managers around Australia through a workshop and series of exercises considering fire danger in a range of fuel types. There was general consensus that the consequences of potential fires escalate with fire danger. At the lower end of the scale, fires are easily controlled and prescribed burns can be conducted safely. At the next level of danger fire suppression becomes challenging and may sometimes fail, but losses are expected to be limited due to successful property protection. Initial attack is expected to mostly succeed. At higher FDR levels, community and firefighter safety become the top priority with decreasing effectiveness of suppression activities and the probability of losses is expected to increase. At these higher FDR levels initial attack will only succeed in the very early stages with significant suppression resources. 


\section{Fire behaviour models and metrics}

The research prototype system uses the best fire spread models that are available and ready for application at present, as presented in Table 1. As outputs, all fire behaviour models provide a measure of rate of spread $\left(\mathrm{m} \mathrm{hr}^{-1}\right)$, and some provide a measure of spotting $(\mathrm{m})$ or flame height/length $(\mathrm{m})$. Another measure we took into account as part of the research prototype is fireline intensity $\left(\mathrm{kW} \mathrm{m}^{-1}\right)$.

Most available fire spread models assume fully dry conditions and a fully developed head fire. A simple measure of fuel availability was used to account for recent rainfall, since use of fully developed head fire spread equations for a fire in damp fuels during the initial attack phase would be inappropriate.

Table 1 - Fire behaviour models used in the research prototype rating system.

\begin{tabular}{lll}
\hline Fire behaviour model & Reference & Fuel type \\
\hline CSIRO Grassland fire spread model & Cheney et al. (1998) & Continuous grasslands \\
\hline CSIRO for northern Australia & Cheney et al. (1998) & Woodlands and savannah \\
\hline Desert spinifex model & Burrows et al. (2015) & Hummock grasslands \\
\hline Buttongrass moorlands model & $\begin{array}{l}\text { Marsden-Smedley and } \\
\text { Catchpole (1995) }\end{array}$ & Buttongrass moorlands \\
\hline $\begin{array}{l}\text { Dry Eucalypt Forest Fire Model } \\
\text { (DEFFM or "Vesta") }\end{array}$ & Cheney et al. (2012) & Dry sclerophyll forests \\
\hline Mallee heath model & Cruz et al. (2013) & Semi-arid mallee heath \\
\hline Heathland model & Anderson et al. (2015) & Temperate shrublands \\
\hline Adjusted pine plantation model & Cruz et al. (2008) & Pine plantations \\
\hline
\end{tabular}

\section{Other metrics}

The behaviour of the head fire is the core of the research prototype rating. However, this is not the whole story. Other things which need to be considered are e.g. atmospheric stability, wind change and spotting potential. In the research prototype we consider:

CHaines index, as a measurement of atmospheric stability,

- A wind change danger index, since wind change can increase the fire danger (a) by causing instability and turbulence in the vicinity of the wind change, or (b) by dramatically increasing the fire size when a fire flank becomes the head fire,

- Bark characteristics and spotting models, for forests with bark fuels.

These aspects were not incorporated into the determination of the rating directly, but were included as 'red flag' warnings.

\section{Fuel classification and data}

Nationally consistent fuel data were used to drive the selection of fire behaviour models and provide the model parameters. Fuel data were derived from national and state datasets classified to common fuel types and aggregated to $1.5 \mathrm{~km}$ resolution to match the scale of the weather forecast and reanalysis grids used to calculate the ratings.

Fuel types have been defined at the level required for selection of appropriate fire behaviour models (Figure 1). There are many vegetation types for which fire behaviour models have not been developed, as they are generally less flammable than the fuel types in Table 1. Classifying these vegetation types into fuel types based on their fuel structure was the best available approach. However, there are often factors limiting the flammability, fuel availability or connectivity, or potential rate of spread in these vegetation types; hence the structurally equivalent models are likely to overestimate fire behaviour. These limitations were treated as modifiers to the model calculation. The fuel attributes included in 
the research prototype were determined based on the requirements of the fire behaviour models. Where local fuel attribute data was not available, a set of generic fuel attributes was applied.

Fire history was used as a modifier to adjust fuel attributes from their peak state using only fires larger than 100 ha.

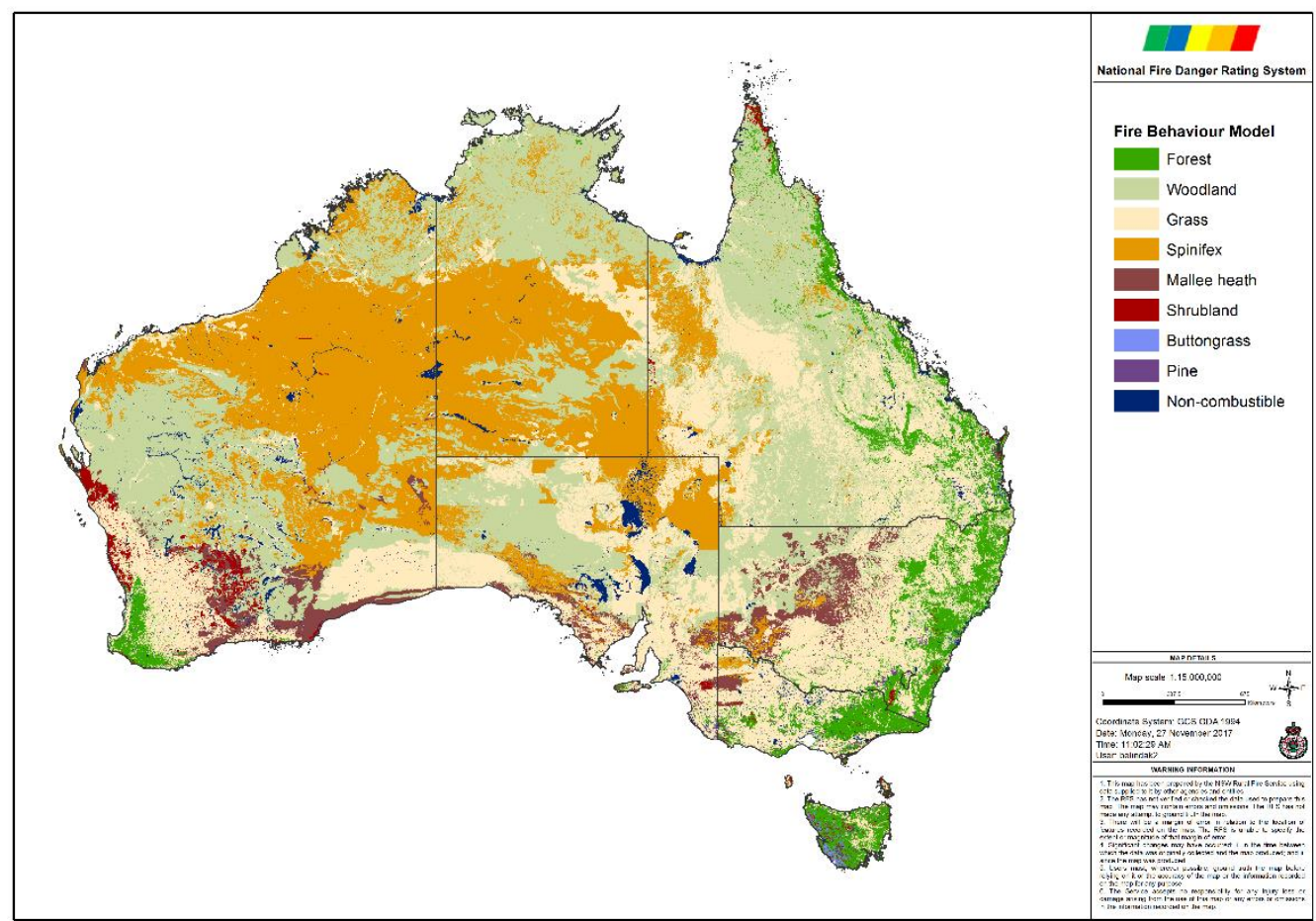

Figure 1 - Map of major fuel types across Australia classified by fire behaviour model

\section{Implementation}

The research prototype system was implemented by the Bureau of Meteorology ahead of the live trial of the system in October 2017. The research prototype algorithms were applied to weather forecasts and base layers (fuels, topography, etc.) using Python scripts. The system produces maps and tables of daily fire danger rating, as well as binary data files containing hourly outputs. Rating products were distributed through existing channels such as a registered user web page and the BoM's FTP service.

\section{Live trial and evaluation}

Ratings from the research prototype system were available during a live trial running from October 2017 to March 2018. Participants compared forecast ratings with the outcomes of incidents using the rating definitions. Historical incidents from agency fire databases and reanalysis weather data were also used in the development and evaluation of the research prototype.

\section{References}

Anderson, W. R., et al. (2015). "A generic, empirical-based model for predicting rate of fire spread in shrublands." International Journal of Wildland Fire 24(4): 443-460.

Burrows, N. D., Liddelow, G. L. \& Ward, B. (2015). A guide to estimating fire rate of spread in spinifex grasslands of Western Australia (Mk2v3). Science and Conservation Division, Department of Parks and Wildlife. 
Cheney, N. P., et al. (1998). "Prediction of fire spread in grasslands." International Journal of Wildland Fire 8(1): 1-13.

Cheney, N. P., Gould, J. S., McCaw, W. L., \& Anderson, W. R. (2012). Predicting fire behaviour in dry eucalypt forest in southern Australia. Forest Ecology and Management, 280, 120-131.

Cruz, M. G., McCaw, W. L., Anderson, W. R., \& Gould, J. S. (2013). Fire behaviour modelling in semi-arid mallee-heath shrublands of southern Australia. Environmental Modelling \& Software, 40, 21-34.

Cruz, M. G., Alexander, M. E., \& Fernandes, P. A. (2008). Development of a model system to predict wildfire behaviour in pine plantations. Australian Forestry, 71(2), 113-121.

Gould and Cruz (2015) Bushfire Fuel Classification. Consultation draft report. Australasian Fire and Emergency Service Authorities Council, Melbourne.

Marsden-Smedley, J. B. and W. R. Catchpole (1995). "Fire modelling in Tasmanian buttongrass moorlands II. Fire behaviour." International Journal of Wildland Fire 5(4): 215-228. 